\title{
A New Tormentic Acid Derivative from Luehea divaricata Mart. (Tiliaceae)
}

\author{
Júlio C. A. Tanaka, Gentil J. Vidotti and Cleuza C. da Silva* \\ Departamento de Química, Universidade Estadual de Maringá, Avenida Colombo, 5790, \\ 87020-900 Maringá - PR, Brazil
}

\begin{abstract}
Um extrato metanólico das folhas de Luehea divaricata (Tiliaceae), vulgarmente conhecida no Brasil como "açoita-cavalo", forneceu um novo triterpeno caracterizado como ácido $3 \beta-p$ hidroxibenzoiloxitormentico [ácido $3 \beta$-( $p$-hidroxibenzoiloxi)-2 $\alpha$-hidroxiurs-12-en-28-óico], juntamente com uma mistura contendo o ácido maslínico, um triterpeno conhecido. As estruturas dos compostos foram estabelecidas por métodos espectroscópicos.
\end{abstract}

A methanolic extract from leaves of Luehea divaricata (Tiliaceae), known in Brazil as "açoitacavalo", yielded two triterpene: a novel characterized as $3 \beta$ - $p$-hydroxybenzoyloxytormentic acid [3 $\beta$-( $p$-hydroxybenzoyloxy)-2 $\alpha$-hydroxyurs-12-en-28-oic acid] and a mixture containing the maslinic acid. The new compound's structure was established by spectroscopic methods.

Keywords: Luehea divaricata, $3 \beta$-p-hydroxybenzoyloxytormentic acid, maslinic acid

\section{Introduction}

The Tiliaceae family has not been extensively studied yet. $\alpha$-Amyrin derivatives have already been isolated from the genus Corchorus. ${ }^{1}$ There is no studies about the chemical composition of this plant and no reports were found on the genus Luehea as well. Luehea divaricata Mart. (Tiliaceae), known in Brazil as "açoita-cavalo", is a tree which grows in Brazil, Argentina and Paraguay., ${ }^{2,3}$ The L. divaricata is used in Brazilian folk medicine for different purposes: the leaves are used as diuretic, the stems as antiinflammatory, ${ }^{4}$ the bark and aerial parts are used for healing skin wounds, pimples, and for vaginal washes. ${ }^{2}$ Also the $L$. divaricata was assayed for antifungal properties and exhibited a broad spectrum of activity against dermatophytes. ${ }^{2}$ The aqueous extract of $L$. divaricata presented genotoxic activity in the Ames test (Salmonellal microsome) with microsomal activation. ${ }^{5}$ However, a phytochemical screening of L.divaricata reported the presence of flavonoids, tannins and saponins. ${ }^{4}$ In this paper we report the isolation and the structure elucidation of a new $\alpha$-amyrin derivative, which was characterized as $3 \beta$ $p$-hydroxybenzoyloxytormentic acid and a mixture containing the maslinic acid.

*e-mail: ccsilva@uem.br

\section{Results and Discussion}

Structural elucidation and NMR signal assignments of 3 $\beta$-p-hydroxybenzoyloxytormentic acid (1)

Compound 1 was isolated as white crystals. Its EIMS spectrum showed a molecular peak at $m / z 608$ in agreement with $\mathrm{C}_{37} \mathrm{H}_{52} \mathrm{O}_{7}$ molecular formula. It also showed a base peak at $\mathrm{m} / \mathrm{z} 121$ attributed to $p$-hydroxybenzoyl cation and also the peaks at $m / z 563\left(10.8 \%,[\mathrm{M}-\mathrm{COOH}]^{+}\right)$and $562\left(17.0 \%,[\mathrm{M}-\mathrm{HCOOH}]^{+}\right)$. The peak at $\mathrm{m} / z .146(61.9 \%$, $\left.\left[\mathrm{C}_{11} \mathrm{H}_{14}\right]^{+*}\right)$ is a characteristic of a tertiary hydroxyl function presence at $\mathrm{C}-19$ in the urs-12-ene skeleton. ${ }^{6}$ Other important peaks were noticed at $\mathrm{m} / \mathrm{z} 246$ (14.0\%), 219 (7.9\%), $218(14.0 \%)$ and $201(5.8 \%)$. Some low relative abundance peaks at $\quad \mathrm{m} / \mathrm{z} 179$ and 264 were detected, as previously related to triterpenes from ursane class. ${ }^{6}$ The ${ }^{1} \mathrm{H}$ chemical shifts of $\mathbf{1}\left(\mathrm{CD}_{3} \mathrm{OD}\right)$, in the range of $\delta$ 0.82-1.37, showed six singlets from methyl groups and one doublet, partly superposed by the singlets in agreement with an ursane type compound. The ${ }^{1} \mathrm{H}$ NMR spectrum of an oleanane type compound has seven methyl singlets and no doublets. ${ }^{7}$ The ${ }^{1} \mathrm{H}$ NMR spectrum also showed two carbinolic methine hydrogens at $\delta 3.90(\mathrm{td}, J 10.3 \mathrm{~Hz}$, $10.3 \mathrm{~Hz}, 4.0 \mathrm{~Hz}, \mathrm{H}-2 \beta)$ and $4.70 \mathrm{ppm}(\mathrm{d}, J 10.3 \mathrm{~Hz}, \mathrm{H}-3 \alpha)$ and one olefinic hydrogen at $\delta 5.30(\mathrm{br} \mathrm{s}, \mathrm{H}-12)$. These data suggested $\mathbf{1}$ to be a triterpene with an ursane skeleton.

The ${ }^{1} \mathrm{H}$ NMR spectral data were compared to those from 


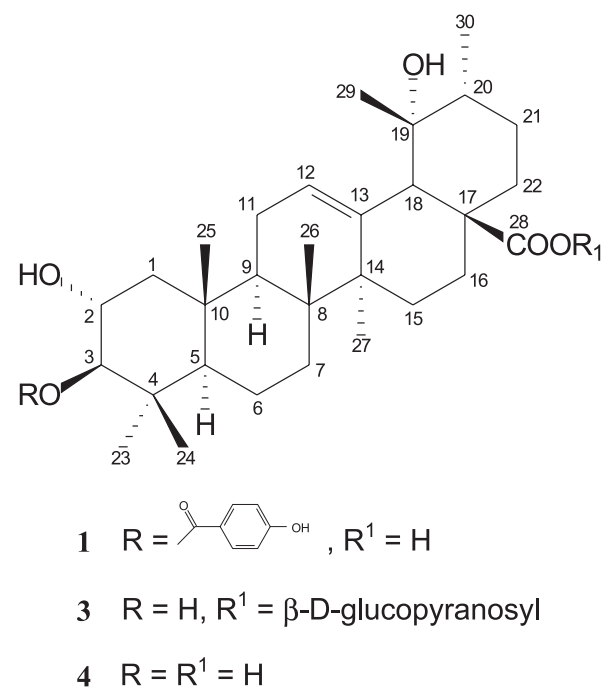

tormentic acid, ${ }^{8}$ and a strong agreement was observed, except the chemical shift corresponding to H-3. The difference $\left(\Delta_{\delta \mathrm{H}}=1.79 \mathrm{ppm}\right)$ of the H-3 chemical shift $\left(\delta_{\mathrm{H}} 4.70\right)$ in respect to tormentic acid ${ }^{8}$ was justified by the presence of a $p$-hydroxybenzoyl group linked to the oxygen of C-3 in compound $\mathbf{1}$, which induces an electron density reduction by inductive and resonance withdrawal effects of the $p$ hydroxybenzoyloxy group. The ${ }^{1} \mathrm{H}$ and ${ }^{13} \mathrm{C}$ NMR spectra's compound had signals for a $p$-hydroxybenzoate group [ $\delta$ $7.92(2 \mathrm{H}, \mathrm{dd}, J 9.0 \mathrm{~Hz}, 2.1 \mathrm{~Hz})$ and $\delta 6.83(2 \mathrm{H}, \mathrm{dd}, J 9.0 \mathrm{~Hz}$, $2.1 \mathrm{~Hz}), \delta 168.7$ (C-7'), 163.6, (C-4'), 133.0 (CH-2' and CH6'), 123.0 (C-1'), 116.2 (CH-3' and CH-5')]. The presence of this group was supported by the observation of a strong peak in the mass spectrum at $\mathrm{m} / \mathrm{z} 121$ corresponding to $\left[\mathrm{C}_{7} \mathrm{H}_{5} \mathrm{O}_{2}\right]^{+\cdot}$. The correlation between $\mathrm{H}-3$ and C-7' observed in HMBC spectrum was very important because it was possible to establish a link between the $p$-hydroxybenzoyl group and the triterpene skeleton from the structure $\mathbf{1}$ in the C-3 position. Initially, compound $\mathbf{1}{ }^{13} \mathrm{C}$ NMR spectrum was run in $\mathrm{CD}_{3} \mathrm{OD}$, however it was also necessary to run in $\mathrm{C}_{5} \mathrm{D}_{5} \mathrm{~N}$ to confirm the presence of the signals that were superposed by the solvent signal in the range of $\delta 48-50$ (Table 1). The ${ }^{13} \mathrm{C}$ NMR spectrum of $\mathbf{1}$ confirmed that is a triterpene skeleton with an ursolic acid type (C-12 and C-13 at $\delta 129.3$ and 140.4). The ${ }^{13} \mathrm{C}$ NMR spectral data of $\mathbf{1}$ were compared with those from tormentic acid ester glucoside. ${ }^{9}$ The coupling constant $\left(J_{2,3}\right)$ of $10.3 \mathrm{~Hz}$ is typical to an antiperiplanar (axialaxial) relationship between $\mathrm{H}-2$ and $\mathrm{H}-3$ (Table 1). The NOE difference NMR experiment was also performed to confirm the $p$-hydroxybenzoyloxy group orientation at C-3. Irradiation of $\mathrm{H}-2 \beta$ signal at $\delta 3.90$ produced an enhancement in the methyl hydrogens resonance at $\delta 1.01(3 \mathrm{H}-24)$ and $1.08(3 \mathrm{H}-25)$ which showed a coaxial relationship between $3 \mathrm{H}-24$ and $3 \mathrm{H}-25$. In the same irradiation, it wasn't observed
NOE enhancement at $\mathrm{H}-3$ or $\mathrm{H}-5$, showing an antiperiplanar relationship between $\mathrm{H}-2$ / $\mathrm{H}-3$ and $\mathrm{H}-2$ / H-5.

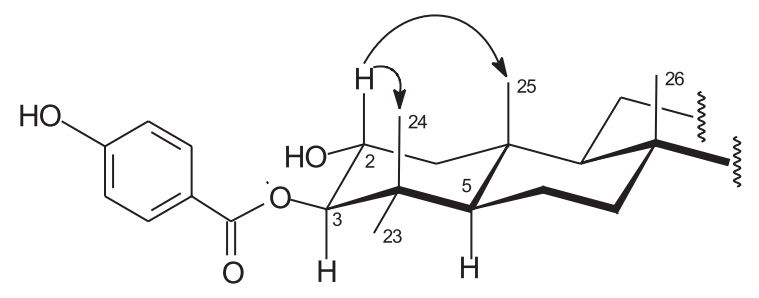

Figure 1. Selected ${ }^{1} \mathrm{H}-{ }^{1} \mathrm{H}$ dipolar correlation of $\mathbf{1}$ observed through NOE difference spectra experiment.

The complete and unequivocal ${ }^{1} \mathrm{H}$ and ${ }^{13} \mathrm{C}$ chemical shifts assignments of 1 were assisted by DEPT, COSY $\left({ }^{1} \mathrm{H} \mathrm{x}\right.$ $\left.{ }^{1} \mathrm{H}\right), \operatorname{HSQC}\left({ }^{13} \mathrm{C} \mathrm{x}{ }^{1} \mathrm{H}\right)$ and $\mathrm{HMBC}\left({ }^{13} \mathrm{C} \mathrm{x}^{1} \mathrm{H}\right)$ spectra (Table 1$)$.

\section{Assignments of maslinic acid (2)}

The 1D ${ }^{1} \mathrm{H}$ NMR from the mixture showed signals for methyl groups $(\delta 0.80-1.16)$, for two carbinolic methine hydrogens at $\delta 2.90(\mathrm{~d}, J 9.9 \mathrm{~Hz}, \mathrm{H}-3 \alpha)$ and $3.61(\mathrm{ddd}, J$ $9.9 \mathrm{~Hz}, 9.9 \mathrm{~Hz}, 3.9 \mathrm{~Hz}, \mathrm{H}-2 \beta)$ and for one olefinic hydrogen at $\delta 5.24(\mathrm{t}, J 3.6 \mathrm{~Hz})$. These data suggested 2 to be a triterpene with an oleanane skeleton. ${ }^{8}$ The ${ }^{13} \mathrm{C}$ NMR spectrum showed the signals at $\delta 145.5,123.6,84.5$ and 69.5 confirming that is olean- 12 -ene- $2 \alpha, 3 \beta$-diol..$^{10}$ Some aspects of the maslinic acid structure was made by comparison of its ${ }^{1} \mathrm{H}$ NMR and ${ }^{13} \mathrm{C}$ NMR data with those proposed to a similar compound. ${ }^{8,10,11}$

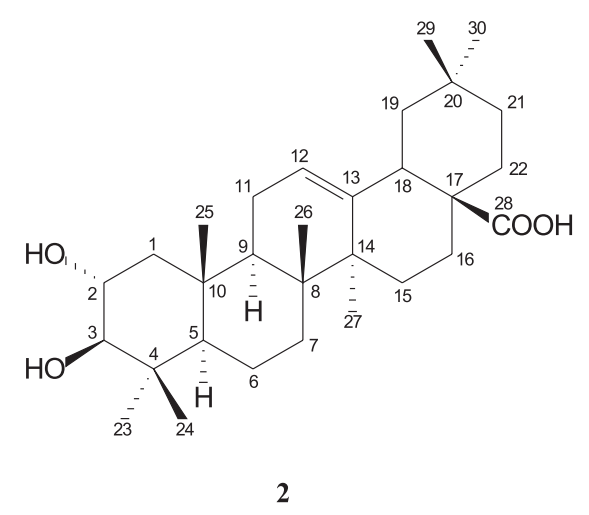

\section{Experimental}

\section{General}

EIMS: $70 \mathrm{eV} ;{ }^{1} \mathrm{H}(300$ or $500 \mathrm{MHz})$ and ${ }^{13} \mathrm{C}(75.5$ or 125 $\mathrm{MHz}$ ) NMR spectra were obtained in pyridine- $d_{5}$ or methanol$d_{4}$ with TMS as internal reference; column chromatography (CC): silica gel 60 (70-230 mesh); thin-layer chromatography (TLC): silica gel F254 (0.25 mm in thickness). 
Table 1. ${ }^{1} \mathrm{H},{ }^{13} \mathrm{C}$ and $2 \mathrm{D}$ NMR spectral data for $3 \beta$-p-hydroxybenzoyloxytormentic acid $(\mathbf{1}),{ }^{13} \mathrm{C}$ NMR data for tormentic acid ester glucoside $(\mathbf{3}){ }^{9}$ and for tormentic acid (4), ${ }^{1} \mathrm{H}$ NMR in $\mathrm{CD}_{3} \mathrm{OD}[\mathbf{1}(300 \mathrm{MHz})$ and $4(400 \mathrm{MHz})]$ and ${ }^{13} \mathrm{C}$ NMR in $\mathrm{CD}_{3} \mathrm{OD}[\mathbf{1}(75.5 \mathrm{MHz})]$ and $\mathrm{C}_{5} \mathrm{D}_{5} \mathrm{~N}[\mathbf{3}(50$ $\mathrm{MHz}]^{\mathrm{a}}$

\begin{tabular}{|c|c|c|c|c|c|}
\hline \multirow[t]{2}{*}{ C (DEPT) } & \multirow{2}{*}{$\begin{array}{c}\delta^{{ }^{13} \mathrm{C}} \\
\mathbf{1}\left(\mathbf{1}^{\mathrm{b}}, \mathbf{3}\right)\end{array}$} & \multicolumn{2}{|c|}{$\delta{ }^{1} \mathbf{H}$} & \multirow{2}{*}{$\begin{array}{c}\operatorname{COSY}\left({ }^{1} \mathbf{H} \times{ }^{1}{ }^{1} \mathbf{H}\right) \\
\mathbf{1}\left({ }^{2} \boldsymbol{J} \text { and }{ }^{3} \boldsymbol{J}\right)\end{array}$} & \multirow{2}{*}{$\begin{array}{c}\text { HMBC }\left({ }^{13} \mathbf{C} \times{ }^{1} \mathbf{H}\right) \\
\boldsymbol{1}\left({ }^{2} \boldsymbol{J},{ }^{3} \boldsymbol{J} \text { and }{ }^{4} \boldsymbol{J}\right)\end{array}$} \\
\hline & & 1 & 4 & & \\
\hline $1\left(\mathrm{CH}_{2}\right)$ & $48.6(48.4,48.0)$ & $1.10 / 2.04 \mathrm{nd}$ & & $\mathrm{H}-1 \mathrm{~b} / \mathrm{H}-1 \mathrm{a} ; \mathrm{H}-2$ & H-5; H-25 \\
\hline $2(\mathrm{CH})$ & $67.7(66.3,68.6)$ & $\begin{array}{l}3.90 \mathrm{td} \\
(10.3,10.3,4.0)\end{array}$ & $\begin{array}{l}3.62 \mathrm{ddd} \\
(9.8 ; 9.8 ; 3.5)\end{array}$ & $\mathrm{H}-1 ; \mathrm{H}-3$ & H-3; H-25 \\
\hline $3(\mathrm{CH})$ & $85.9(85.2,83.8)$ & $4.70 \mathrm{~d}(10.3)$ & $2.91 \mathrm{~d}(9.8)$ & $\mathrm{H}-2$ & H-23; H-24 \\
\hline $4(\mathrm{C})$ & $41.1(40.2,38.5)$ & & & & H-3; H-5; H-23; H-24 \\
\hline $5(\mathrm{CH})$ & $56.5(55.4,56.0)$ & $1.04 \mathrm{nd}$ & & H-6 & H-23; H-24; H-25 \\
\hline $6\left(\mathrm{CH}_{2}\right)$ & $19.5(18.6,19.1)$ & $1.59 \mathrm{nd}$ & & $\mathrm{H}-5 ; \mathrm{H}-7$ & $\mathrm{H}-5 ; \mathrm{H}-25$ \\
\hline $7\left(\mathrm{CH}_{2}\right)$ & $34.0(33.1,33.5)$ & $1.37 / 1.64 \mathrm{nd}$ & & H-6 & H-26 \\
\hline $8(\mathrm{C})$ & $40.8(40.2,40.6)$ & & & & $\mathrm{H}-27$ \\
\hline $9(\mathrm{CH})$ & $48.6(47.5,47.9)$ & $1.82 \mathrm{nd}$ & & $\mathrm{H}-11$ & H-5; H-25; H-26 \\
\hline $10(\mathrm{C})$ & $39.2(38.3,39.9)$ & & & & $\mathrm{H}-25$ \\
\hline $11\left(\mathrm{CH}_{2}\right)$ & $24.7(23.9,24.2)$ & $2.04 \mathrm{nd}$ & & $\mathrm{H}-12 ; \mathrm{H}-9$ & \\
\hline $12(\mathrm{CH})$ & $129.3(127.7,128.2)$ & $5.30 \mathrm{br} \mathrm{s}$ & $5.28 \mathrm{t}(3.2)$ & $\mathrm{H}-11$ & $\mathrm{H}-18$ \\
\hline $13(\mathrm{C})$ & $140.4(140.1,139.5)$ & & & & H-18; H-27 \\
\hline $14(\mathrm{C})$ & $42.7(42.2,42.3)$ & & & & H-27; H-26 \\
\hline $15\left(\mathrm{CH}_{2}\right)$ & $29.6(29.1,29.3)$ & $1.02 / 1.85 \mathrm{nd}$ & & H-15b / H-15a; H-16 & $\mathrm{H}-27$ \\
\hline $16\left(\mathrm{CH}_{2}\right)$ & $27.3(26.7,26.8)$ & $1.28 / 1.75 \mathrm{nd}$ & & H-16b / H-16a; H-15 & $\mathrm{H}-18$ \\
\hline $17(\mathrm{C})$ & $48.6(48.1,48.6)$ & & & & H-18 \\
\hline $18(\mathrm{CH})$ & $55.1(54.5,54.4)$ & $2.51 \mathrm{~s}$ & $2.50 \mathrm{~s}$ & & $\mathrm{H}-29$ \\
\hline $19(\mathrm{C})$ & $73.7(72.6,72.6)$ & & & & H-18; H-29; H-30 \\
\hline $20(\mathrm{CH})$ & $43.1(42.0,42.2)$ & $1.37 \mathrm{nd}$ & & $\mathrm{H}-30$ & H-30; H-29; H-18 \\
\hline $21\left(\mathrm{CH}_{2}\right)$ & $26.6(26.2,26.1)$ & $1.54 / 2.59 \mathrm{nd}$ & & $\mathrm{H}-21 \mathrm{~b} / \mathrm{H}-21 \mathrm{a}$ & $\mathrm{H}-30$ \\
\hline $22\left(\mathrm{CH}_{2}^{2}\right)$ & $39.0(38.2,37.8)$ & $1.75 \mathrm{nd}$ & & & \\
\hline $23\left(\mathrm{CH}_{3}\right)$ & $29.2(28.8,29.5)$ & $0.90 \mathrm{~s}$ & & & $\mathrm{H}-3 ; \mathrm{H}-24$ \\
\hline $24\left(\mathrm{CH}_{3}\right)$ & $18.3(16.5,16.8)$ & $1.01 \mathrm{~s}$ & & & $\mathrm{H}-3 ; \mathrm{H}-23$ \\
\hline $25\left(\mathrm{CH}_{3}\right)$ & $17.0(16.6,17.1)$ & $1.08 \mathrm{~s}$ & & & \\
\hline $26\left(\mathrm{CH}_{3}\right)$ & $17.5(18.1,17.8)$ & $0.82 \mathrm{~s}$ & & & \\
\hline $27\left(\mathrm{CH}_{3}\right)$ & $24.8(24.5,24.6)$ & $1.37 \mathrm{~s}$ & & & \\
\hline $28(\mathrm{C})$ & $182.7(180.8,176.9)$ & & & & H-18 \\
\hline $29\left(\mathrm{CH}_{3}\right)$ & $27.0(26.9,27.0)$ & $1.20 \mathrm{~s}$ & & & \\
\hline $30\left(\mathrm{CH}_{3}\right)$ & $16.5(17.0,17.5)$ & $0.93 \mathrm{~d}(6.6)$ & & $\mathrm{H}-20$ & \\
\hline $1^{\prime}(\mathrm{C})$ & $123.0(122.7,-)$ & & & & $\mathrm{H}-3^{\prime} ; \mathrm{H}^{-} 5^{\prime}$ \\
\hline $2^{\prime}, 6^{\prime}(\mathrm{CH})$ & $133.0(132.5,-)$ & $7.92 \mathrm{dd}(9.0,2.1)$ & & $\mathrm{H}^{-} 3^{\prime}, \mathrm{H}-5^{\prime}$ & H-6', H-2' \\
\hline $3^{\prime}, 5^{\prime}(\mathrm{CH})$ & $116.2(116.0,-)$ & $6.83 \mathrm{dd}(9.0,2.1)$ & & $\mathrm{H}-2$, , H-6' & $\mathrm{H}-5, \mathrm{H}-3$, \\
\hline $4^{\prime}(\mathrm{C})$ & $163.6(163.4,-)$ & & & & H-3'; H-5'; H-2'; H-6' \\
\hline $7^{\prime}(\mathrm{C})$ & $168.7(167.0,-)$ & & & & H-3; H-2'; H-6' \\
\hline
\end{tabular}

a Values are in $\mathrm{ppm}(\delta)$. Coupling constants $(J)$, in parentheses, are in $\mathrm{Hz} ;{ }^{\text {b }}{ }^{13} \mathrm{C}$ NMR in $\mathrm{C}_{5} \mathrm{D}_{5} \mathrm{~N}(75.5 \mathrm{MHz})$.

\section{Plant material}

The plant was collected in April 1999, Mandacaru stream, Maringá city, State of Paraná, Brazil and identified by Dr. Maria Conceição de Souza, Universidade Estadual de Maringá. A voucher specimen (HUM 9057) was kept at the herbarium of the Biological Department of Universidade Estadual de Maringá.

\section{Isolation}

Air-dried and powdered leaves (600 g) of L. divaricata Mart., were extracted with $\mathrm{MeOH}$ at room temp. The $\mathrm{MeOH}$ extract was concentrated in vacuum and yielded $74 \mathrm{~g}$ of crude methanolic extract. Part of the crude methanolic extract $(38 \mathrm{~g})$ was partitioned with $\mathrm{n}$-hexane $(600 \mathrm{~mL})$, chloroform $(600 \mathrm{~mL})$, ethyl acetate $(600 \mathrm{~mL})$ and methanol (100 mL), yielding $5.8 \mathrm{~g}(15.3 \%), 2.9 \mathrm{~g}(7.6 \%), 4.9 \mathrm{~g}$ (12.9\%), $24 \mathrm{~g}(63.2 \%)$ respectively. The choroformic fraction was subjected to $\mathrm{CC}$ on silica gel $(70 \mathrm{~g})$ and eluted with different rations of $\mathrm{n}$-hexane, $\mathrm{CHCl}_{3}$ and $\mathrm{MeOH}$. The appropriate frs (monitored by TLC analysis) were combined resulting in 22 frs. Fr 14 (160 mg), eluted with chloroform-methanol (90:10), was subjected to repeated $\mathrm{CC}$ on silica gel, eluted with $\mathrm{n}$-hexane, chloroform and methanol mixts of increasing polarity to give $3 \beta-p$ hydroxybenzoyloxytormentic acid (1) (2.8 mg-1.8\%) and a mixture containing maslinic acid (2) (4.3 mg-2.7\%).

$3 \beta$-p-hydroxybenzoyloxytormentic acid (1). White crystals. EIMS $\mathrm{m} / z$ (rel. int.): [M]+• 608,563 (10.8), 562 
(17.0), 264 (<3.0), 246 (14.0), 219 (7.3), 218 (14.1), 201 (5.8), 189 (31.8), 187 (15.6), 179 (<3.0), 146 (61.9), 121 (100).

Maslinic acid (2). White crystals. ${ }^{13} \mathrm{C}$ NMR (75.5 MHz, $\mathrm{CD}_{3} \mathrm{OD}$ ): 48.1 (C-1), 69.5 (C-2), 84.5 (C-3), 40.5 (C-4), 56.7 (C-5), 19.5 (C-6), 33.9 (C-7), 39.2 (C-8), 49.0 (C-9), 39.2 (C-10), 24.0 (C-11), 123.6 (C-12), 145.5 (C-13), 42.6 (C-14), 28.8 (C-15), 24.0 (C-16), 47.7 (C-17), 42.7 (C-18), 47.2 (C-19), 31.6 (C-20), 34.9 (C-21), 33.8 (C-22), 29.3 (C-23), 17.0 (C-24), 17.1 (C-25), 17.4 (C-26), 23.9 (C-27), 180.0 (C-28), 33.5 (C-29), 23.9 (C-30).

\section{Acknowledgements}

The authors thanks CAPES for scholarships and CNPq for financial support. We also thanks Dr. M. C. de Souza for support in the plant collection and for the identification of the plant material, Dr. A. J. Marsaioli (Unicamp) for running the HSQC and HMBC spectra.

\section{References}

1. Khan, M. S. Y.; Javed, K.; Khan, M. H.; Shamsi, M. A.; Siddiqui, A. A.; Phytochemistry 1991, 30, 1989.
2. Zacchino, S.; Santecchia, C.; Lopez, S.; Gattuso, S.; Muñoz, J. de D.; Cruañes, A.; Vivot, E.; Cruañes, M. del C.; Salinas, A.; Ruiz, R. E. de; Ruiz, S.; Phytomedicine 1998, 5, 389.

3. Lorenzi, H.; Árvores Brasileiras: Manual de Identificação e Cultivo de Plantas Arbóreas Nativas do Brasil / Harri Lorenzi, $2^{\text {th }}$ ed., Plantarum: Nova Odessa, 1998.

4. Alice, C. B.; Silva, G. A. A. B.; Cad. Farm. 1985, 1, 83.

5. Vargas, V. M. F.; Guidobono, R. R.; Henriques, J. A. P.; Mem. I. Oswaldo Cruz 1991, 86, 67.

6. Delgado, G.; Hernández, J.; Pereda-Miranda, R.; Phytochemistry 1989, 28, 1483.

7. Biessels, H. W. A.; Hoof, A. C. K.; Bosch, J. J. K.; Salemink, C. A.; Phytochemistry 1974, 13, 203.

8. Yamagishi, T.; Zhang, D-C.; Chang, J-J.; McPhail, D. R.; McPhail, A. T.; Lee, K-H.; Phytochemistry 1988, 27, 3213.

9. Gopalsamy, N.; Vargas, D.; Guého, J.; Ricaud, C.; Hostettmann, K.; Phytochemistry 1988, 27, 3593.

10. Bilia, A. R.; Mendez, J.; Morelli, I.; Acta Pharm. Helv. 1996, $71,191$.

11. Zucaro, Z.; Yasmin, L.; Compagnone, R.S.; Hess, S.C.; Delle Monache, F.; J. Braz. Chem. Soc. 2000, 11, 241.

Received: January 18, 2002 Published on the web: March 26, 2003 